\title{
Development and Validation of a UV-Spectrophotometric Method for the Quantitative Determination of Oxcarbazepine and Study of its Degradation Profile
}

Deepakumari HN and Revanasiddappa HD*

Department of Chemistry, University of Mysore, India

\begin{abstract}
Oxcarbazepine $(\mathrm{OXC})$ has attracted much attention owing to its multiple health benefits. OXC is an anticonvulsant and mood stabilizing drug, used primarily in the treatment of epilepsy. This study developed and validated a simple, specific, sensitive and reliable stability indicating UV-Spectrophotometric method for the quantitative determination of oxcrbazepine in pure and in pharmaceutical dosage forms. Analysis was performed using methanol: aceonitrile (50:50) as diluents. UV detection was performed at $254 \mathrm{~nm}$. The calibration plot was linear over a concentration range of 0.0-15 $\mathrm{g} \mathrm{mll}^{-1}$ with correlation coefficient values $>0.9986$. The method was validated for specificity, linearity, precision, accuracy, limit of detection, limit of quantification and robustness. The forced degradation studies were performed by using $\mathrm{HCl}, \mathrm{NaOH}, \mathrm{H}_{2} \mathrm{O}_{2}$, thermal and UV radiation. Oxcarbazepine is more sensitive towards alkaline conditions and very much resistant towards acidic, oxidative and photolytic degradations. The method was validated as per ICH guidelines. The RSD for intra- and inter-day precision were found to be lesser than $3 \%$. The percentage recovery was in good agreement with the labeled amount in the pharmaceutical formulations and the method is simple, specific, precise and accurate for the determination of oxcarbazepine in pharmaceutical formulations
\end{abstract}

Keywords: Oxcarbazepine; UV-Spectrophotometry; Pharmaceutical preparations; Stress studies

\section{Introduction}

UV-Vis Spectrophotometer (UV) is long-used analytical equipment with property of high sensitivity and selectivity. It can be widely used in pharmaceutical, biochemical, food, life-science industries for R\&D, quality assurance and other applications.

Oxcrabazepine (OXC) is chemically known as, 10,11-dihydro-10oxo-5H-dibenz (b,f) azepine-5-carboxamide (Figure 1). OXC, is a keto analog of carbamazepine and is an anticonvulsant and mood stabilizing drug. OXC is known to exert antiepileptic activity by blockade of voltage-dependent sodium channels in the brain. It protects mice and rats against generalized tonic-clonic seizures induced by electroshock which is thought to act via inhibition of sodium channel activity. It is commercially available under trade names, Oxrate (Wockhard), Oxetol (Sun Pharma), Oxcarb (Cipla) etc. The drug is not yet official in any pharmacopoeias.

OXC is used to treat seizures, several types of epilepsy and in management of intractable trigeminal neuralgia. In treatment of epilepsy, oxcarbazepine has recently been found to be associated with a greater enhancement in mood and reduction in anxiety symptoms than other drugs employed to treat epilepsy [1]. Oxcarbazepine is a prodrug which is activated to eslicarbazepine in the liver [2].

To date, all analytical methods described in literature for the determination of OXC in pharmaceuticals or in biological and other matrices involve voltammetry [3], chiral liquid chromatography method with ultraviolet detection (LC-UV) [4,5], micellar electrokinetic chromatography [6], microemulsion electrokinetic chromatography [7], HPLC [8-20], capillary electrophoresis [21], GCMS [22] and spectrophotometry [23-29]. The reported methods in the literature suffer from one or the other disadvantage such as poor sensitivity [23-26,28], scrupulous control of experimental variables, time consuming [27,29], costly reagents [26,29] and uses heating steps [29]. Since, very few methods are reported in the literature and no stability indicating method is available in the official compendia using UV-Spectrophotometry for analyzing of OXC in dosage forms. Hence there is a need to develop a simple, rapid, accurate and precise spectrophotometric method for the determination of OXC in tablets as an alternative method to stability indicating HPLC methods. Comparison of the performance characteristics of the existing visible spectrophotometric methods with the proposed method is shown in Table 1.

The presented work is aimed at the development and validation of a new analytical method for determination of the anticonvulsant drug oxcarbazepine according to the current ICH guidelines [30]. A

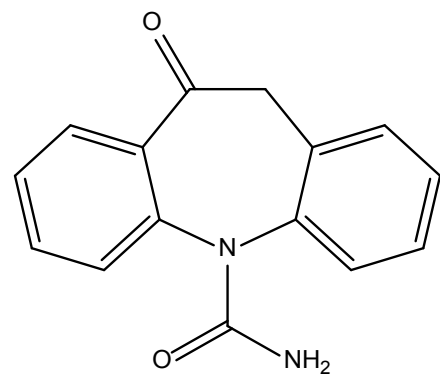

Figure 1: Structure of oxcarbazepine.

*Corresponding author: Revanasiddappa HD, Professor, Department of Chemistry, University of Mysore, Manasagangothri, Mysore, India, Tel: 919449271137; E-mail: hdrevanasiddappa@yahoo.com

Received March 11, 2014; Accepted March 24, 2014; Published April 02, 2014

Citation: Deepakumari HN, Revanasiddappa HD (2014) Development and Validation of a UV-Spectrophotometric Method for the Quantitative Determination of Oxcarbazepine and Study of its Degradation Profile. Chem Sci J 5: 084. doi: 10.4172/2150-3494.1000084

Copyright: (C) 2014 Deepakumari HN, et al. This is an open-access article distributed under the terms of the Creative Commons Attribution License, which permits unrestricted use, distribution, and reproduction in any medium, provided the original author and source are credited. 
Page 2 of 7

\begin{tabular}{|c|c|c|c|c|c|}
\hline SI. No. & Reagent/s used & Methodology & $\begin{array}{l}\text { Linear range, } \mathrm{\mu g} \mathrm{ml}^{-1} \text { and molar } \\
\text { absorptivity, } \mathrm{I} \mathrm{mol}^{-1} \mathrm{~cm}^{-1}\end{array}$ & Remarks & References \\
\hline 1 & & $\begin{array}{l}\text { The absorbance of green colored chromogen } \\
\text { was measured at } 770 \mathrm{~nm}\end{array}$ & $\begin{array}{c}4-28 \mu \mathrm{g} \mathrm{ml}^{-1} \\
\left(€=4.63 \times 10^{3}\right)\end{array}$ & Less sensitive & [23] \\
\hline 2 & $\begin{array}{l}\text { Anthranilic acid and } \\
\text { 2-chlorophenylhydrazine }\end{array}$ & $\begin{array}{l}\text { Colored condensation product showed } \\
\text { absorption maximum at } 485 \mathrm{~nm}\end{array}$ & - & Less sensitive & [24] \\
\hline 3 & Folin-Ciocalteu phenol reagent (FCP) & $\begin{array}{l}\text { The absorbance of the intense blue color of the } \\
\text { reduced FCP was measured at } 760 \mathrm{~nm} \\
\text { OXC undergoes oxidative coupling with MBTH } \\
\text { to form }\end{array}$ & $\begin{aligned} & 5-30 \\
&(€=\left.8.06 \times 10^{3}\right) \\
& 10.0-50\end{aligned}$ & $\begin{array}{l}\text { Less sensitive } \\
\text { Less sensitive }\end{array}$ & [25] \\
\hline 4 & $\begin{array}{l}\text { 3-methyl- } \\
\text { 2-benzothiazolinone hydrazine } \\
\text { hydrochloride (MBTH) }\end{array}$ & $\begin{array}{l}\text { green colored chromogen, measured at } 456 \\
\mathrm{~nm}\end{array}$ & $\left(€=3.126 \times 10^{3}\right)$ & $\begin{array}{l}\text { Less sensitive } \\
\text { and the use of } \\
\text { costly reagent }\end{array}$ & [26 ] \\
\hline 5 & $\begin{array}{l}N \text {-bromosuccinimide (NBS) and } \\
\text { bromopyrogallol red (BPR) as reagents }\end{array}$ & $\begin{array}{l}\text { The absorbance of the unreacted BPR was } \\
\text { measured at } 460 \mathrm{~nm}\end{array}$ & $\left(€=2.52 \times 10^{4}\right)$ & $\begin{array}{l}\text { The reagent is } \\
\text { not stable and } \\
\text { requires } \\
30 \text { min for color } \\
\text { development }\end{array}$ & [27] \\
\hline 6 & $\begin{array}{l}\text { Methanol }(\text { method } A) \\
\text { and acetonitrile }(\text { method } B)\end{array}$ & $\begin{array}{l}\text { Shows maximum absorbance at } 254 \mathrm{~nm} \\
\text {--same--- }\end{array}$ & $2-40$ & Less sensitive & [28] \\
\hline 7 & $\begin{array}{l}\text { Use of Cerium(IV) and leuco dyes as } \\
\text { reagents (Proposed methods) }\end{array}$ & $\begin{array}{l}\text { The absorbance of crystal violet was measured } \\
\text { at } 580 \mathrm{~nm}(\operatorname{method} \mathrm{A}) \\
\text { bluish-green } \\
\text { colored malachite green at } 610 \mathrm{~nm} \text { (method } \\
\text { B) and } \\
\text { blue color of xylene cyanol FF at } 610 \mathrm{~nm} \\
\text { (method C) }\end{array}$ & $\begin{aligned} & 0.0-2.5 \\
(€= & \left.3.86 \times 10^{4}\right) \\
& 0.0-2.0 \\
(€= & \left.4.41 \times 10^{4}\right) \\
& \\
& 0.0-2.5 \\
(€= & \left.2.16 \times 10^{4}\right)\end{aligned}$ & $\begin{array}{l}\text { Sensitive but } \\
\text { requires heating }\end{array}$ & [29] \\
\hline 8 & Methanol:aceonitrile & UV-spectrophotometry & $0.0-15$ & Highly sensitive & $\begin{array}{l}\text { Developed } \\
\text { method }\end{array}$ \\
\hline
\end{tabular}

Table 1: Comparison of the performance characteristics of the existing visible spectrophotometric methods with the proposed method.

thorough literature survey reveals that, there is no method available for the quantitative determination of oxcarbazepine in pure and in pharmaceuticals by UV-Spectrophotomtric (stability indicating) technique using methanol: aceonitrile. Hence, the author has presented a simple, highly sensitive and cost-effective spectrophotometric technique using methanol: aceonitrile as diluents.

\section{Experimental}

\section{Apparatus}

Spectrophotometric analysis for the study of spectral and absorbance measurements was carried out on a Systronics model 118 UV-Vis Spectrophotometer provided with $1 \mathrm{~cm}$ matched quartz cells.

\section{Reagents and standards}

All chemicals and reagents used were of analytical reagent grade and HPLC grade acetonitrile and methanol was purchased from Merck (Mumbai, India).

Preparation of standard OXC solution: Pharmaceutical grade OXC certified to be $99.99 \%$ pure was received from Cipla India Ltd., Mumbai, India, as a gift and was used as received. A stock standard solution equivalent to $100 \mu \mathrm{g} \mathrm{ml}^{-1}$ of $\mathrm{OXC}$ was prepared by dissolving $10 \mathrm{mg}$ of the pure drug in $50 \mathrm{ml}$ methanol and diluted to $100 \mathrm{ml}$ with acetonitrile. Working solutions were prepared as required by dilution.

Pharmaceutical formulations of oxcarbazepine such as Oxrate 150 mg, (Wockhard), Oxetol $150 \mathrm{mg}$ (Sun Pharma) and Mezalog $150 \mathrm{mg}$ (La Pharma) were purchased from local markets.

\section{General procedures}

Preparation of calibration curve: Aliquots of standard solution

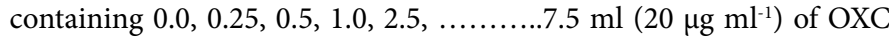
were transferred into a series of $10 \mathrm{ml}$ calibrated flasks using micro burette and the volume was made up to the mark with acetonitrile. Absorbance of each solution was measured at $254 \mathrm{~nm}$ against acetonitrile, (blank). Calibration curve was prepared by plotting absorbance vs. concentration of drug. Concentration of unknown was read from the concurrent calibration curve or the regression equation using Beer's law data.

Procedure for tablets: For analysis of the tablet dosage forms, twenty tablets from each brand (Oxrate, Oxetol and Mezalog tablets) were ground into fine powder and quantity of the powder equivalent to $10 \mathrm{mg}$ of OXC was weighed accurately into a three separate $100 \mathrm{ml}$ calibrated flasks and $50 \mathrm{ml}$ of methanol was added. The content was shaken for about $30 \mathrm{~min}$; the volume was diluted to the mark with acetonitrile and mixed well and filtered using a Whattman no.41 filter paper. The filtrate containing OXC was at a concentration $100 \mu \mathrm{g}$ $\mathrm{ml}^{-1}$ was subjected to analysis by the procedure described above after suitable dilution step.

Analysis of placebo blank: A placebo blank containing starch 10 $\mathrm{mg}$, methyl cellulose $15 \mathrm{mg}$, gum acacia $20 \mathrm{mg}$, talc $15 \mathrm{mg}$, magnesium stearate $15 \mathrm{mg}$ and sodium alginate $10 \mathrm{mg}$ was prepared by combining all these components to form a homogenous mixture. $10 \mathrm{mg}$ of placebo blank was accurately weighed and its solution was prepared as described under "Procedure for tablets", and then subjected to analysis as described under procedure for the "Preparation of calibration curve".

Analysis of synthetic mixture: To the placebo blank of the composition described above, $10 \mathrm{mg}$ OXC was added into a $100 \mathrm{ml}$ calibrated flask and homogenized, and the solution was prepared as described under "Procedure for tablets", and then subjected to analysis by the procedure described under "Preparation of calibration curve". The analysis was used to study the interferences of excipients such as talc, acacia, starch, methyl cellulose, sodium citrate, sodium alginate and magnesium stearate.

Forced degradation studies: Forced degradation studies were 
carried out for OXC to provide an indication of the stability indicating property and specificity of proposed method. Forced degradation of drug substances was carried out under acidic, basic, oxidative, photolytic and thermal stress conditions.

Acid and base decomposition: Solutions for acid and alkaline degradation studies were prepared by taking $2.5 \mathrm{ml}$ of $20 \mu \mathrm{g} \mathrm{ml}^{-1}$ OXC separately in two $10 \mathrm{ml}$ calibrated flasks and mixed with $1 \mathrm{M}$ hydrochloric acid (acid hydrolysis) and $0.1 \mathrm{M} \mathrm{NaOH}$ (base hydrolysis), respectively. All the solutions were stored at $80^{\circ} \mathrm{C}$ for $8 \mathrm{~h}$. Then, the solution was cooled to room temperature and diluted to the mark with acetonitrile, and the absorption spectra of the resulting solutions were recorded.

Oxidation studies: Oxidative degradation study was performed using hydrogen peroxide solution at room temperature. Solution for use in oxidation studies was prepared by taking $2.5 \mathrm{ml}\left(20 \mu \mathrm{g} \mathrm{ml}^{-1}\right)$ OXC in a $10 \mathrm{ml}$ calibrated flask and mixed with $5 \% \mathrm{H}_{2} \mathrm{O}_{2}$. Then, the solution was kept at room temperature for $8 \mathrm{~h}$ and diluted to the mark with acetonitrile, and the absorption spectra of the resulting solutions were recorded.

Photolytic degradation: Photo degradation studies were carried out by exposing the drug solution $\left(20 \mu \mathrm{g} \mathrm{ml}^{-1}\right)$ as well as powder drug in a photo stability chamber for 3 days. The powder was spread as a thin layer in a petri plate. The samples of both solution and powder were kept in parallel in darkness (wrapped) for the same period.

Thermal degradation studies: To investigate the susceptibility of the drug under thermal stress conditions, the drug was spread in a borosilicate glass petri-dish and placed in the hot-air oven maintained at $80^{\circ} \mathrm{C}$ for $8 \mathrm{~h}$ and after cooling to room temperature, $1 \mathrm{mg}$ of OXC was weighed and transferred to a $100 \mathrm{ml}$ calibrated flask, dissolved in acetonitrile and diluted up to the mark with the same solvent. The absorption spectrum was recorded from 230-400 $\mathrm{nm}$.

\section{Results and Discussion}

\section{Absorption spectra}

Attempt has been made to develop a rapid, highly sensitive, precise and accurate analytical method for oxcarbazepine in pure and in dosage forms. The proposed UV method allows rapid and economical quantitation of OXC in tablets without any time-consuming sample preparation. Moreover, the spectrophotometric method involves simple instrumentation compared with other instrumental techniques. Further, OXC stock solutions and working standards were made in methanol:acetonitrile $(50: 50, \mathrm{v} / \mathrm{v})$ and acetonitrile, respectively. It showed maximum absorption maximum at $254 \mathrm{~nm}$, and at this wavelength acetonitrile (blank), had no significant absorbance. The absorption spectrum of OXC is presented in Figure 2.

\section{Results of forced degradation}

The ICH guideline provides useful definitions and general comments about forced degradation studies. Stress testing provides evidence on how the quality of a drug may be affected under the influence of different stress conditions. The degradation products can cause changing of chemical, pharmacological and toxicological properties of drugs having significant impact on product quality and safety [31]. The OXC sample in acidic, oxidative $\left(5 \% \mathrm{H}_{2} \mathrm{O}_{2}\right)$ and thermal hydrolysis showed $1.27,2.54$ and $1.01 \%$ degradation, respectively. The photolytic degradation was not observed when OXC was exposed in solid state to UV light for 3 days. The drug was found to be more stable to acidic hydrolysis as compared to alkaline hydrolysis. Major degradation up to $15.73 \%$ occurred under alkaline conditions. Therefore, it may be concluded that OXC is more susceptible to alkaline, less susceptible to acidic and oxidative and stable towards thermal and photolytyic conditions. Percent degradation was calculated by comparing the absorbance values of the drug degraded in each degradation condition with the corresponding absorbance values of the drug under non-degradation condition. Based on the previous report $[32,33]$, the absorption spectrum (Figures 3a-c) obtained under basic, oxidative and acidic conditions shows degradation of OXC, whereas the absorption spectrum obtained under photolytic and thermal conditions shows no or negligible degradation of OXC and the summary of forced degradation results are shown in Table 2.

\section{Method validation}

The method developed was validated as per ICH/USP guidelines for parameters like linearity and sensitivity, limits of detection (LOD) and quantitation (LOQ), precision, accuracy, ruggedness, selectivity and recovery.

Linearity, sensitivity, limits of detection and quantitation: Linearity is usually expressed in terms of the variance around the slope of regression line, and is calculated according to an established mathematical relationship from test results obtained by the analysis of samples with varying concentrations of analyte. Under the established experimental conditions, a linear correlation was found between the absorbance at respective wavelengths and concentration of OXC in the ranges is given in Table 3. Regression analysis of the calibration curve (Figure 4) using the method of least-squares was made to calculate the slope (b), intercept (a) and correlation co-efficient (r) and the values are presented in Table 3. The optical characteristics such as absorption maxima, Beer's law limit, molar absorptivity and Sandell's sensitivity values [34] are also given in Table 3.

The limit of detection (LOD) and limit of quantification (LOQ) evaluated as per ICH guidelines using the formulas:

$$
\begin{aligned}
& \mathrm{LOD}=\frac{3.3 \times \sigma}{\mathrm{s}} \\
& \mathrm{LOQ}=\frac{10 \times \sigma}{\mathrm{s}}
\end{aligned}
$$



Figure 2: Absorption spectrum for $\left.\mathrm{OXC}(5 \mu \mathrm{g} \mathrm{ml})^{-1}\right)$. 
Citation: Deepakumari HN, Revanasiddappa HD (2014) Development and Validation of a UV-Spectrophotometric Method for the Quantitative Determination of Oxcarbazepine and Study of its Degradation Profile. Chem Sci J 5: 084. doi: 10.4172/2150-3494.1000084

Page 4 of 7

\begin{tabular}{|c|c|c|c|c|}
\hline Degradation condition & Time & * Drug decomposed (\%) & * \% of drug remaining after degradation & Remarks \\
\hline $\mathrm{HCl} 1 \mathrm{M}$ at $80^{\circ} \mathrm{C}$ & $8 \mathrm{~h}$ & 1.27 & 88.73 \\
\hline $\mathrm{NaOH} 0.1 \mathrm{M}$ at $80{ }^{\circ} \mathrm{C}$ & $8 \mathrm{~h}$ & 15.73 & 94.27 \\
\hline $\begin{array}{c}\text { Oxidation by } \mathrm{H}_{2} \mathrm{O}_{2} \\
(5 \%), \text { at room temp. }\end{array}$ & $8 \mathrm{~h}$ & 2.54 & 97.46 \\
\hline Thermal solid, $80^{\circ} \mathrm{C}$ & $8 \mathrm{~h}$ & 1.01 & 98.99 \\
\hline $\mathrm{UV}$ & 3days & 0.97 & 99.03 \\
\hline
\end{tabular}

*Mean value of three replicates

Table 2: Summary of forced degradation results.

\begin{tabular}{|c|c|}
\hline Parameter & Method \\
\hline$\lambda_{\max } \mathrm{nm}$ & 254 \\
\hline Beer's law range $\left(\mu \mathrm{g} \mathrm{ml}^{-1}\right)$ & $0.0-15$ \\
\hline Linear range $\left(\mu \mathrm{g} \mathrm{ml}^{-1}\right)$ & $0.5-12.5$ \\
\hline Molar absorptivity $(\varepsilon),\left(\mid \mathrm{mol}^{-1} \mathrm{~cm}^{-1}\right)$ & $1.34 \times 10^{4}$ \\
\hline Sandell sensitivity $\left(\mu \mathrm{g} \mathrm{cm}^{-2}\right)$ & 0.0188 \\
\hline Intercept (a) & 0.0147 \\
\hline Slope (b) & 0.0458 \\
\hline Correlation coefficient ( $r$ ) & 0.9986 \\
\hline $\mathrm{LOQ}\left(\mu \mathrm{g} \mathrm{ml}^{-1}\right)$ & 0.1667 \\
\hline $\operatorname{LOD}\left(\mu \mathrm{g} \mathrm{ml}^{-1}\right)$ & 0.0550 \\
\hline
\end{tabular}

${ }^{*} y=a+b x$, where $x$ is the concentration of $O X C$ in $\mu \mathrm{g} \mathrm{ml}^{-1}$ and $y$ is the absorbance at $254 \mathrm{~nm}$; $S_{a}$ is the standard deviation of the intercept, $S_{b}$ is the standard deviation of the slope.

Table 3: Analytical and regression parameters of the proposed method.

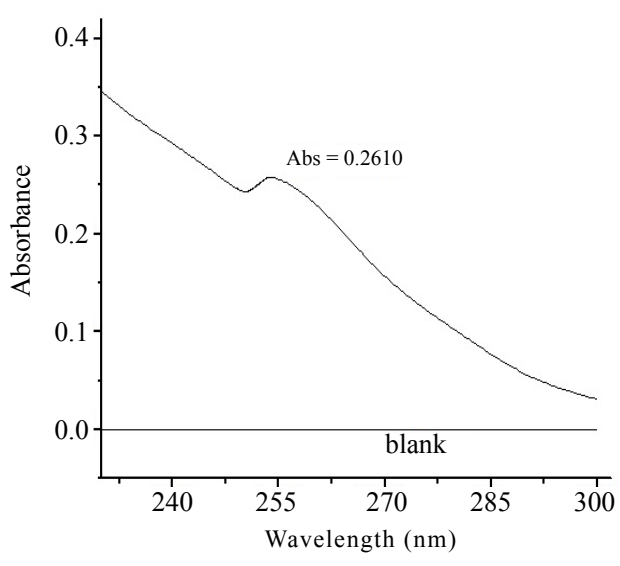

A

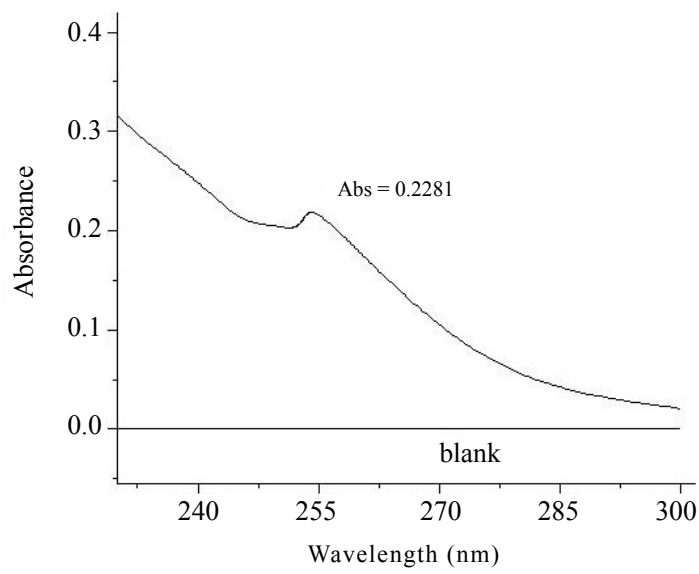

B



C

Figure 3 (a): Acid degradation, (b): Base degradation (c): Oxidative degradation. 
Citation: Deepakumari HN, Revanasiddappa HD (2014) Development and Validation of a UV-Spectrophotometric Method for the Quantitative Determination of Oxcarbazepine and Study of its Degradation Profile. Chem Sci J 5: 084. doi: 10.4172/2150-3494.1000084

Page 5 of 7

Where $\sigma$ is the standard deviation $(n=5)$ of reagent blank determination and $s$ is the slope of the calibration curve.

Precision and accuracy: The intra-day and inter-day precision and accuracy of the proposed method was established by replicate analysis of OXC samples at three different concentrations (low, medium and high) (Table 4) within the working limits, each being repeated five times. The relative error, RE (\%) and relative standard deviation, RSD (\%) values of both intra and inter-day studies were satisfactory and showed that the best appraisal of the procedures in daily use. The analytical results obtained from this investigation are summarized in Table 4 . The values percentage relative error between the concentrations of OXC for taken and found showed the high accuracy of the method. The results obtained are presented in Tables 4 and 5 and show that the accuracy is good.
Application to analysis of pharmaceutical samples: The method was applied successfully to the determination of OXC in dosage forms. To check the validity of the proposed method, OXC was determined in Oxrate, Oxetoland Mezalogtablets and the results are presented in Table 6 . The results of an assay were statistically compared with the reference method [28] by applying the Student's $t$ - test for accuracy and $F$ - test for precision. The results in the Table 6 showed that there is no significant difference between the proposed and the reference method at the $95 \%$ confidence level with respect to accuracy and precision. The calculated $t$ - and $F$ - values (Table 6 ) did not exceed the tabulated values $(t=2.77$ and $F=6.39$ ).

Recovery study: The accuracy and precision of the proposed method was further ascertained by performing recovery studies. Preanalyzed tablet powder was spiked with pure drug at three different concentrations and the total was found by the proposed method. Each

\begin{tabular}{|c|c|c|c|c|c|c|c|}
\hline & \multirow[b]{2}{*}{ OXC taken, $\mu \mathrm{g} \mathrm{ml}^{-1}$} & \multicolumn{3}{|c|}{ Intra-day accuracy and precision } & \multicolumn{3}{|c|}{ Inter-day accuracy and precision } \\
\hline & & $\begin{array}{l}\text { OXC found } \\
\mathrm{ml}^{-1}\end{array}$ & RE, \% & RSD, \% & $\begin{array}{l}\text { OXC found } \\
\mathrm{ml}^{-1}\end{array}$ & RE, \% & RSD, \% \\
\hline \multirow{3}{*}{ Proposed Method } & 2.5 & 2.48 & 0.67 & 1.03 & 2.51 & -0.55 & 1.37 \\
\hline & 7.5 & 7.45 & 0.71 & 1.34 & 7.56 & -0.74 & 1.09 \\
\hline & 12.5 & 12.38 & 0.96 & 0.88 & 12.60 & -0.83 & 2.56 \\
\hline
\end{tabular}

RE: Relative error; RSD: Relative standard deviation;

* Mean value of 5 determinations

** Mean value of 3 determinations

Table 4: Evaluation of accuracy and precision.

\begin{tabular}{|c|c|c|c|}
\hline & \multirow{2}{*}{ OXC taken, $\mu \mathrm{g} \mathrm{ml}^{-1}$} & \multicolumn{2}{|c|}{ Ruggedness } \\
\hline & & Inter-analysts ( $\%$ RSD), $n=3$ & Inter-instruments ( $\%$ RSD), $n=3$ \\
\hline \multirow{3}{*}{ Proposed Method } & 2.5 & 1.95 & 2.10 \\
\hline & 7.5 & 1.64 & 1.76 \\
\hline & 12.5 & 1.79 & 1.99 \\
\hline
\end{tabular}

Table 5: Method Ruggedness expressed as intermediate precision (\% RSD).

\begin{tabular}{|c|c|c|c|}
\hline \multirow{2}{*}{ Tablet brand Name* } & \multirow{2}{*}{ Nominal amount mg per tablet } & \multicolumn{2}{|c|}{ Found ${ }^{* *}(\%$ of nominal amount \pm SD) } \\
\hline & & Reference method & Proposed Method \\
\hline Oxrate $^{a}$ & $150 \mathrm{mg}$ & $99.8 \pm 0.80$ & $\begin{array}{c}100.05 \pm 1.02 \\
t=0.33, F=1.61\end{array}$ \\
\hline Oxetol $^{b}$ & $150 \mathrm{mg}$ & $99.1 \pm 1.10$ & $\begin{array}{c}100.28 \pm 0.83 \\
t=1.83, F=0.57\end{array}$ \\
\hline Mezalog ${ }^{\mathrm{c}}$ & $150 \mathrm{mg}$ & $99.12 \pm 0.66$ & $\begin{array}{c}100.79 \pm 1.14 \\
t=1.99, F=2.98\end{array}$ \\
\hline
\end{tabular}

*Marketed by, a. Wockhard, b. Sun Pharma, c. La Pharma

${ }^{* *}$ Mean value of five determinations

Tabulated $t$ - and $F$-values at $95 \%$ confidence level are 2.77 and 6.39 , respectively.

Table 6: Results of determination of OXC in tablets and statistical comparison with the reference method.

\begin{tabular}{|c|c|c|c|c|}
\hline \multirow{2}{*}{ Tablet brand name } & \multicolumn{4}{|c|}{ Method } \\
\hline & OXC tablet solution added, $\mu \mathrm{g} \mathrm{ml}^{-1}$ & Pure OXC added, $\mu \mathrm{g} \mathrm{ml}^{-1}$ & Total found $\mu \mathrm{g} \mathrm{ml}^{-1}$ & Pure OXC recovered* $\% \pm S D$ \\
\hline \multirow{3}{*}{ Oxrate } & 5 & 2.5 & 7.49 & $99.78 \pm 0.93$ \\
\hline & 5 & 5 & 10.04 & $100.83 \pm 1.11$ \\
\hline & 5 & 7.5 & 12.47 & $99.55 \pm 1.01$ \\
\hline \multirow{3}{*}{ Oxetol } & 5 & 2.5 & 7.49 & $99.96 \pm 0.68$ \\
\hline & 5 & 5 & 10.02 & $101.04 \pm 0.80$ \\
\hline & 5 & 7.5 & 12.49 & $99.84 \pm 1.01$ \\
\hline \multirow{3}{*}{ Mezalog } & 5 & 2.5 & 7.52 & $100.83 \pm 0.68$ \\
\hline & 5 & 5 & 10.06 & $101.27 \pm 1.11$ \\
\hline & 5 & 7.5 & 12.52 & $100.28 \pm 1.62$ \\
\hline
\end{tabular}

* Mean value of three measurements.

Table 7: Results of recovery experiments via the standard addition technique. 
Citation: Deepakumari HN, Revanasiddappa HD (2014) Development and Validation of a UV-Spectrophotometric Method for the Quantitative Determination of Oxcarbazepine and Study of its Degradation Profile. Chem Sci J 5: 084. doi: 10.4172/2150-3494.1000084



Figure 4: Calibration curve for OXC.

determination was repeated three times. The recovery of the pure drug added was quantitative and revealed that frequently encountered common ingredients of tablet formulations were found not to interfere with the proposed spectrophotometric method. The results of recovery study are compiled in Table 7.

\section{Conclusions}

The proposed method for the estimation of OXC was found to be simple, sensitive and reliable with good precision and accuracy. The method is specific while estimating the commercial formulations without interference from any components of pharmaceutical dosage forms or degradation products was observed. The behavior of OXC under various stress conditions was studied; the degradation of the drug under alkaline condition was identified by the change in the absorbance values and presented in Figure 3b. i.e., OXC is more sensitive towards alkaline conditions and very much resistant towards acidic, oxidative and photolytic degradations. The information presented here in could be very useful for quality monitoring of bulk samples and as well employed to check the quality of drug during stability studies.

\section{Competing Interests}

The authors declare that they have no competing interests.

\section{References}

1. Mazza M, Marca GD, Di Nicola M, Pozzi G, Janiri L, et al. (2007) Oxcarbazepine improves mood in patients with epilepsy. Epilepsy Behav10: 397-401.

2. Dulsat C, Mealy N (2009) Eslicarbazepine acetate. Drugs of the Future.34: 189.

3. Rao KS, Calvo MEB (2007) Determination of oxcarbazepine by Square Wave Adsorptive Stripping Voltammetry in pharmaceutical preparations. J Pharm Biomed Anal 43: 1156-1160.

4. Fortuna A, Alves G, Anabela A, Lopes B, Falcão A, et.al. (2012) A chiral liquid chromatography method for the simultaneous determination of oxcarbazepine, eslicarbazepine, R-licarbazepine and other new chemical derivatives BIA 2-024, BIA 2-059 and BIA 2-265, in mouse plasma and brain. Biomed Chromatogr 26: 384-392.

5. Levert $\mathrm{H}$, Odou $\mathrm{P}$, Robert $\mathrm{H}$ (2002) LC determination of oxcarbazepine and its active metabolite in human serum. J Pharm Biomed Anal 28: 517-525.

6. Pucci V, Kenndler E, Raggi MA (2003) Quantiation of oxcarbazepine and its metabolites in human plasma by micellarelectrokinetic chromatography. Biomed Chromatogr 17: 231-238.

7. Von Unruh GE, Paar WD (1986) Gas chromatographic/mass spectrometric assays for oxcarbazepine and its main metabolites, 10-hydroxy-carbazepine and carbazepine-10, 11-trans-diol. Biomed Environ Mass Spectrom 13: 651-656.
8. Rao KS, Belorkar N, MEB Rao (2009) Development and validation of stabilityindicating liquid chromatographic method for the quantitative determination of oxcarbazepine in tablet dosage forms. Pharm Anal 1: 270-277.

9. Mandrioli R, Ghedini N, Albani F, Kenndler E, Raggi MA (2003). Liquid chromatographic determination of oxcarbazepine and its metabolite in plasma of epileptic patients after solid-phase extraction. J Chromatogr B AnalytTechnol Biomed Life Sci 783: 253-263.

10. Contin M, Balboni M, Callegati E, Candela C, Albani F, et al. (2005) Simultaneous liquid chromatographic determination of lamotrigine,oxcarbazepi nemonohydroxy derivative and felbamate in plasma of patients with epilepsy. $J$ Chromatogr B AnalytTechnol Biomed Life Sci 828: 113-117.

11. Mazzucchelli I, Franco V, Cinzia F, Roberto M, Emilio P, et al. (2007) a Novel EnantioselectiveMicroassay for the High-Performance Liquid Chromatography Determination of Oxcarbazepine and Its Active Metabolite Monohydroxycarbazepine in Human PlasmaTher Drug Monit 29: 319-324.

12. Kimiskidis V, Spanakis M, loannis Niopas, Dimitrios Kazis, Chrysi Gabrieli, et al. (2007) Development and validation of a high performance liquid chromatographic method for the determination of oxcarbazepine and its main metabolites in human plasma and cerebrospinal fluid and its application to pharmacokinetic study. J Pharm Biomed Anal 43: 763-768.

13. Chi DY, Li ZD (2006) Yaowu Fenxi Zazhi 26: 1195-1198.

14. Klys M, Rojek S, Bolechała F (2005) Determination of oxcarbazepine and its metabolites in postmortem blood and hair by means of liquid chromatography with mass detection (HPLC/APCI/MS). J Chromatogr B: Anal Technol Biomed Life Sci. 825: 38-46.

15. Mandrioli R, Ghedini N, Albani F, Kenndler E, Raggi MA. (2003) Liquid chromatographic determination of oxcarbazepine and its metabolite in plasma of epileptic patients after solid-phase extraction. J Chromatogr B: Anal Techno Biomed Life Sci 783: 253-263.

16. Rouan MC, Decherf M, Le Clanche V, Lecaillon JB, Godbillon J (1994) Automated microdialysis of oxcarbazepine and its monohydroxy and transdio metabolites in plasma by liquid chromatography. J Chromatogr B: Biomed Appl 658: 167-172.

17. Hartley R, Green M, Lucock MD, Ryan S, Forsythe WI (1991) Solid phase extraction of oxcarbazepine and its metabolites from plasma for analysis by high performance liquid chromatography. Biomed Chromatogr 5: 212-215.

18. Kumps A (1984) Simultaneous HPLC determination of oxcarbazepine carbamazepine and their metabolites in serum. J Liq Chromatogr Relat Tech 7: $1235-1241$.

19. Menge G, Dubois JP (1983) Determination of oxcarbazepine in human plasma by high-performance liquid chromatography. J Chromatogr B: Biomed Appl 275: 189-194.

20. Noirfalise A, Collinge A (1983) Quantitative determination of oxcarbazepine. J Chromatogr B: Biomed Appl 274: 417-420.

21. Von Unruh GE, Paar WD (1985) Gas chromatographic assay for oxcarbazepine and its main metabolites in plasma. J Chromatogr 345: 67-76.

22. Calvo MEB, Renedo OD, Martínez MJ (2007) Determination of oxcarbazepine by square wave adsorptive stripping voltametry in pharmaceutical preparations. J Pharm Biomed Anal 43: 1156-1160.

23. Ramaa CS, Chothe PP, AA Naik, VJ Kadam (2006) Spectrophotometric method for the estimation of oxcarbazepine in tablets. Ind J Pharm Sci 68: 265-266.

24. Krishna $\mathrm{CH}$, Murali Rao SV, Venkata Rao, Malleswara N V S, Rambabu C (2011) Spectrophotometric determination of oxcarbazepine by condensation reactions using 2-chlorophenylhydrazine and anthranilic acid. J Pharm Res 4 : 3317-3319.

25. Rajendraprasad N, Basavaiah K(2012)Application of 3-methylbenzothiazolin2-one hydrazone for the quantitative spectrophotometric determination of oxcarbazepine in pharmaceuticals with cerium(IV) and periodate. J App Spectro 79: 616-622.

26. Gandhimathi M, Ravi TK (2008) Use of Folin-Ciocalteu phenol reagent and 3-methyl-2-benzothiazolinone hydrazine hydrochloride inthe determination of oxcarbazepine in pharmaceuticals. Acta Pharm 58: 111-118.

27. Rajendraprasad N, Basavaiah K, Kanakapura B, Vinay (2011) Titrimetric and Spectrophotometric Assay of Oxcarbazepine in Pharmaceuticals Using NBromosuccinimide and Bromopyrogallol Red. Int J Anal Chem 2011: 1-8. 
Citation: Deepakumari HN, Revanasiddappa HD (2014) Development and Validation of a UV-Spectrophotometric Method for the Quantitative Determination of Oxcarbazepine and Study of its Degradation Profile. Chem Sci J 5: 084. doi: 10.4172/2150-3494.1000084

Page 7 of 7

28. Basavaiah K, Rajendraprasad N, Cijo MX, Vinay KB, Ramesh PJ (2011) Development and validation of stability indicating spectrophotometric methods for determination of oxcarbazepine in pharmaceuticals. J Scilnd Res 70: 346351.

29. Deepakumari HN, Revanasiddappa HD (2011) Development and validation of indirect visible spectrophotometric methods for oxcarbazepine in pure and the tablet dosage form. Arab J Chem 4.

30. International Conference On Harmonization of Technical Requirements for Registration of Pharmaceuticals for Human Use, ICH Harmonised Tripartite Guideline, Validation of Analytical Procadures: Text and Methodology Q2(R 1), Complimentary Guideline on Methodology, dated 06 November 1996 incorporated in November 2005, London.
31. Tonnesen $\mathrm{HH}$ (2001) Formulation and stability testing of photolabile drugs. Int J Pharm 225: 1-14

32. Pathare DB, Jadhav AS, Shingare MS (2007) A validated stability indicating LC method for oxcarbazepine. J Pharm Biomed Anal 43: 1825-1830.

33. Raghavi K, Sindhura M, Prashanthi R, Nalluri, Buchi N (2012) Studies on forced degradation of oxcarbazepine using LC-MS compatiblestability indicating RPHPLC method. J Chem Pharm Res 4: 3885-3893.

34. Zavis H, Ludvik D (1976) Handbook of Organic Reagents in Inorganic Analysis. Translated by Stanislav, K, Dr. Chalmers (The Series and Translation Editor: University of Aberdem, Ellis Horwood Limited, Chichester, A Division of John Wiley \& Sons IC, New York, London, Sydney, Toronto., pp.364. 